Middlekamp, J.N. \& Haffner, H. (1963) Carcinoma of the colon in children. Pediatrics, 32, 558.

Morson, B.C. \& Bussey, H.J.R. (1970) Predisposing Causes of Intestinal Cancer-(monograph) Chicago, p. 31. Year Book Publishers, Inc.

O'BRIEN, S.E. (1967) Carcinoma of the colon in childhood and adolescence. Canadian Medical Association Journal, 96, 1217.
StalPoRT, J. \& Letawe, P. (1971) Gardner's syndrome associated with malignant degeneration of a polyp of Oddi's sphincter. Acta gastro-enterologica belgica, 34, 644.

Wolfman, E.F., Astler, V.B. \& Coller, F.A. (1957) Mucoid adenocarcinoma of colon and rectum. Surgery, St Louis, 42, 846.

\title{
Familial dwarfism: case report
}

\author{
S. NADER \\ B.Sc., M.R.C.P. \\ J. A. FISHER \\ M.A., M.B., B.Chir.
}

\author{
F. H. DOYLE \\ F.F.R. \\ K. MASHiter \\ Ph.D. \\ G. F. JOPLIN \\ Ph.D., F.R.C.P.
}

\begin{abstract}
Summary
Three sisters are described, of consanguinous parents, with multiple trophic hormone deficiencies presenting as short stature. In two of them the size of the sella turcica is large in relation to the skeletal age and height. All three show an acute metabolic response to an administered preparation of human growth hormone.
\end{abstract}

\section{Introduction}

Growth hormone deficiency resulting in short stature may occur in the absence of an obvious structural lesion in the pituitary-hypothalamic area as an isolated defect or as part of the syndrome of idiopathic hypopituitarism. Both may occur sporadically or in families (Goodman, Grumbach and Kaplan, 1968). Studies of families suggest autosomal recessive inheritance (Trygstad and Seip, 1964). Until recently it was only possible to guess that trophic hormone deficiency existed by extrapolating from tests of pituitary function but with the availability of gonadotrophin releasing hormone (LH/FSH-RH) and thyrotrophin releasing hormone (TRH) and serum assays for pituitary hormones defective pituitary reserve can be documented. Job et al. (1972) showed a failure of thyrotrophin (TSH) to rise in response to TRH in a dwarfed child who had growth hormone deficiency and Chaussain et al. (1972) have tested gonadotrophin reserve in similar children. In their series of five patients with growth hormone deficiency, one female had a normal gonadotrophin reserve and four males had impaired or absent reserves.

Radiological studies have shown that the pituitary fossa size of one-third of patients with idiopathic hypopituitarism is abnormally small, the volume being more than two standard deviations below the age and height related means of the control group (Underwood et al., 1973). This is in keeping with the findings of Goodman et al. (1968) and our own experience.

The nitrogen retaining and hypercalcuric action of growth hormone can be used to test growth hormone responsiveness in susceptible subjects. Though there are conflicting reports as to prognostic use as far as future growth is concerned (Melvin et al., 1967; Clayton, Tanner and Vince, 1971) these tests are of value in demonstrating target organ sensitivity to an administered preparation of human growth hormone.

We report on three sisters, of consanguinous healthy parents, with multiple trophic hormone deficiencies presenting as short stature. Our data includes assessment of their pituitary function, their acute response to human growth hormone and we 
also describe rather unusual radiological features of the sella turcica.

\section{Case history}

$\mathrm{A}, \mathrm{S}$ and $\mathrm{K}$, three sisters aged 10 years 4 months, 12 years 9 months and 17 years 6 months respectively were referred for investigation and treatment of short stature. The pregnancies had been uneventful and their sizes, though not measured, were believed to be normal at birth. At the age of 2-3 years, growth retardation was noted in each although all have continued to grow slowly. Intelligence is judged as normal for their chronological age. There has been no sexual development in any.

The parents are first cousins: their heights are normal and the mid-parental height is 'average' by British standards. There is no family history of short stature and seven other siblings are said to be of normal height.

\section{Examination}

Figure 1 shows their general appearance and Fig. 2 their heights in relation to the 3rd, 50th and 97th centiles for British children (Tanner, 1958). Measurements of upper and lower segments revealed normal

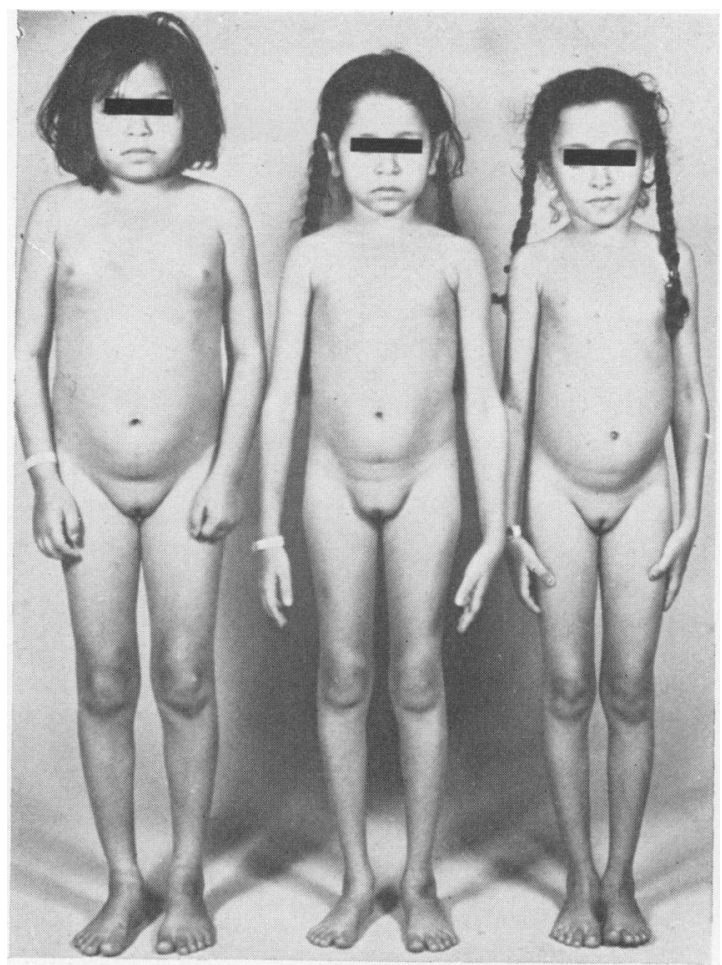

FIG. 1. From right to left, $A, S$ and $K$ aged 10 years 4 months, 12 years 9 months and 17 years 6 months respectively.

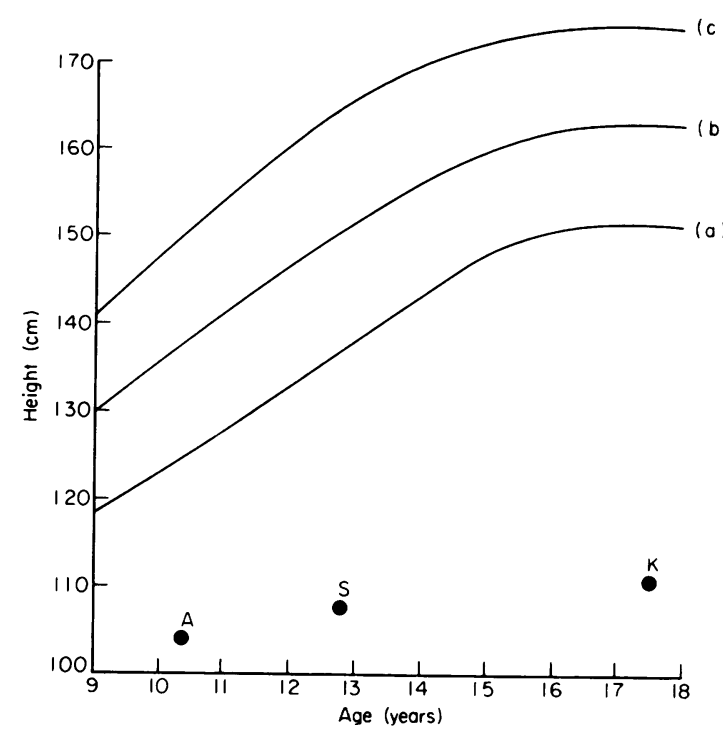

FIG. 2. Growth chart indicating present heights of $A, S$ and $K$ in relation to the (a) $3 \mathrm{rd}$, (b) 50 th and (c) 97 th height centiles for British children (Tanner, 1958).

adult proportions and their head circumferences were normal in relation to their heights. They ha soft skin, immature facies and were all prepubertap Clinically, they were euthyroid and euadrenal. AE ov three had blue sclerae and in $\mathbf{S}$ this was quite conspicuous.

\section{Investigations \\ General}

Routine urinalysis, blood urea, creatinine, calcium, phosphate, electrolytes and fasting blood sugars were within normal limits. All of them were slightly anaemic and blood films were suggestive of thalassaemia trait: this was tested for in the eldest and $\beta$ thalassaemia trait confirmed. All had normal electrocardiograms. Chromosome studies showed normal karyotypes and faecal fat excretion was normal in all three.

\section{Radiology}

Their bone ages were $2.5,3.5$ and 4 years and their dental ages 7,10 and 10 years respectively. Skull $X$ rays in $A$ and $K$ showed a slightly ballooned sella, which also appeared large in relation to the size of the skull (Fig. 3). In these two, the lateral area was more than 2 standard deviations above the mean for skeletal age and height. This abnormality was still evident when pituitary volume was measured and compared with the normal range for their skeletal age (Fisher and Di Chiro, 1964). S had a normallooking sella (Fig. 4) and its lateral area was close to the mean for her skeletal age. Figure 5 shows the 


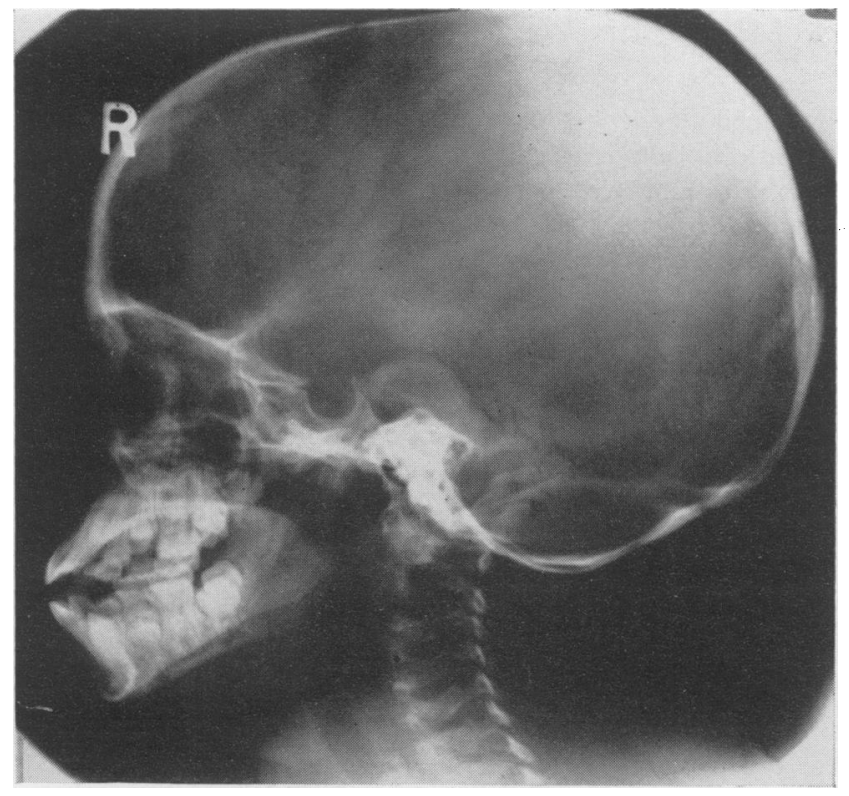

Fig. 3. Lateral skull $\mathrm{X}$-ray in $\mathrm{K}$ showed a ballooned sella, large in relation to the size of the skull.

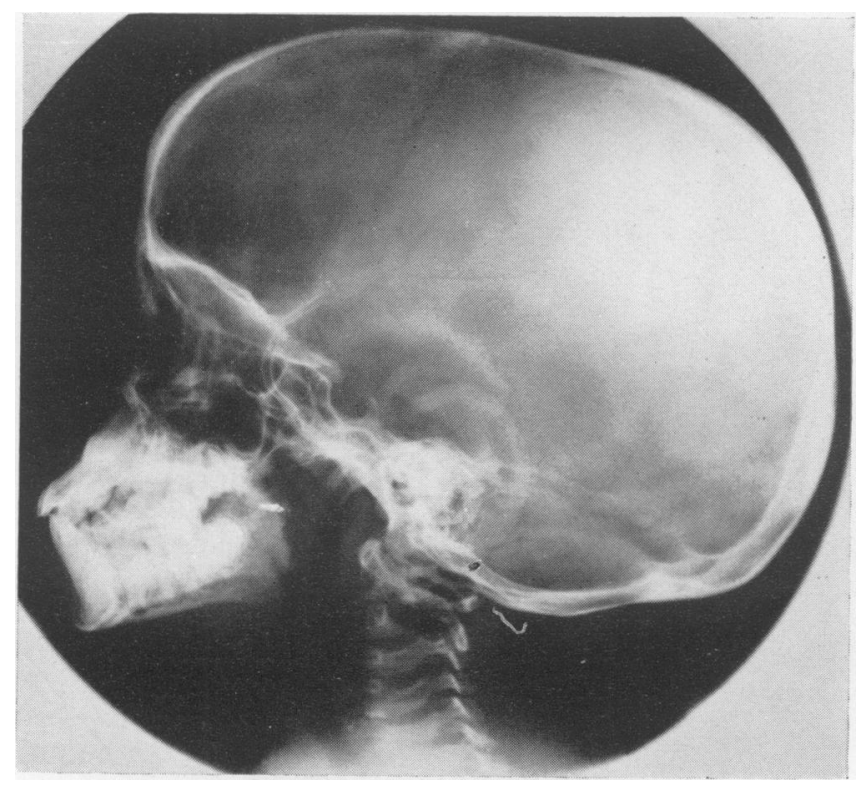

Fig. 4. Lateral skull $\mathrm{X}$-ray in $\mathrm{S}$ showing a sella that is normal in relation to the size of the skull. 


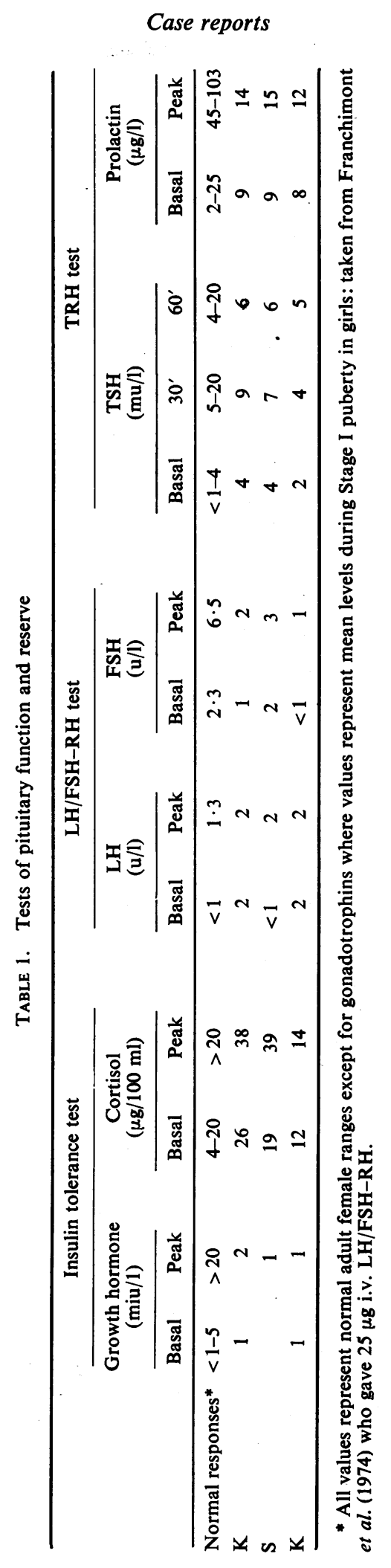




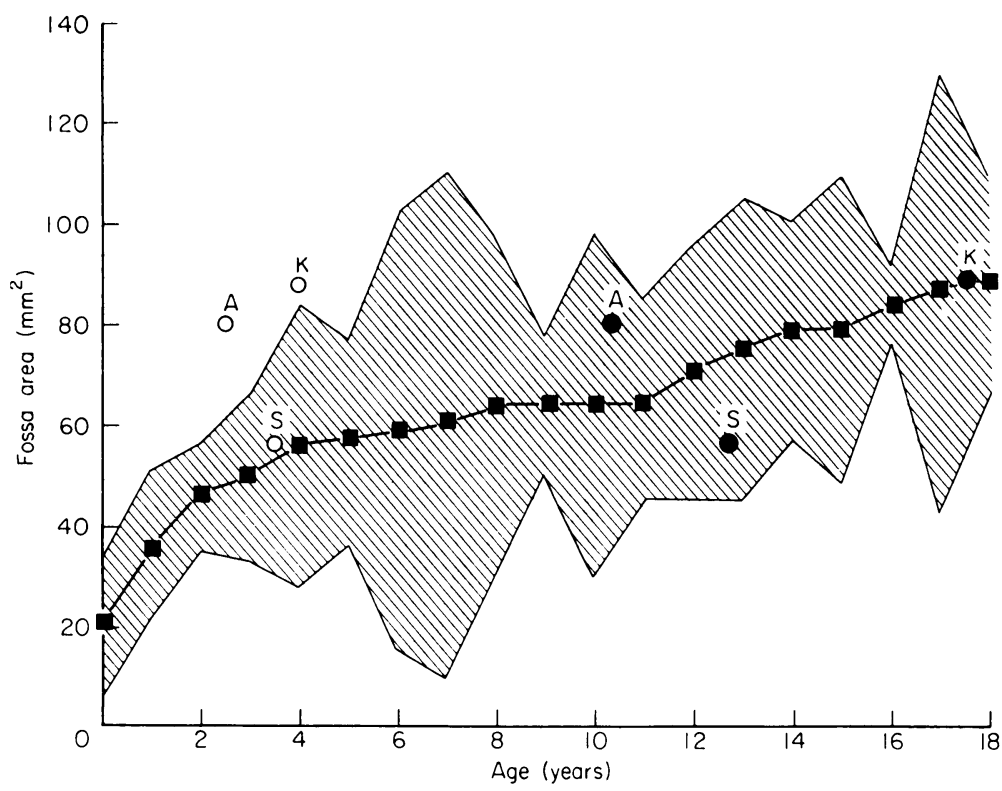

Fig. 5. Lateral sella areas in A, S and $\mathrm{K}$ plotted against chronological age (O) and skeletal age (O). The shaded portion represents the mean area \pm 2 standard deviations found in normal children at different ages (Silverman, 1957).

TABLE 2. Tests of thyroid function

\begin{tabular}{lccc}
\hline & $\begin{array}{c}\text { PBI } \\
(\mu \mathrm{g} / 100 \mathrm{ml})\end{array}$ & $\begin{array}{c}\text { Serum thyroxine } \\
(\mathrm{ng} / \mathrm{ml})\end{array}$ & $\begin{array}{c}\text { Serum cholesterol } \\
(\mathrm{mg} / 100 \mathrm{ml})\end{array}$ \\
\hline Normal range & $4-8$ & $50-120$ & up to 240 \\
A & 5.9 & 85 & 229 \\
$\mathrm{~S}$ & 3.9 & 80 & 234 \\
$\mathrm{~K}$ & 1.8 & 28 & 358 \\
\hline
\end{tabular}

TABLE 3. Acute metabolic response to human growth hormone

\begin{tabular}{lccc}
\hline & $\begin{array}{c}\text { Mean fall in } \\
\text { serum urea } \\
(\mathrm{mg} / 100 \mathrm{ml})\end{array}$ & $\begin{array}{c}\text { Mean fall in } \\
\text { urine urea } \\
(\mathrm{g} / 24 \mathrm{hr})\end{array}$ & $\begin{array}{c}\text { Mean rise in } \\
\text { urine calcium } \\
(\mathrm{mg} / 24 \mathrm{hr})\end{array}$ \\
\hline $\begin{array}{l}\text { Hypopituitary } \\
\text { subjects* }\end{array}$ & $7-19$ & $3-8$ & $40-140$ \\
A & 16 & $2 \cdot 7$ & 42 \\
S & 13 & $3 \cdot 1$ & 57 \\
K & 15 & 5 & 23 \\
\hline
\end{tabular}

* Data from Melvin et al. (1967) using 10 iu of human growth hormone daily for 3 days.

lateral sella areas in all three children plotted against skeletal and chronological age and compared with the sella areas found in normal children (Silverman, 1957).

\section{Endocrine}

(a) Pituitary function (Table 1). A combined test of anterior pituitary function was carried out as described by Harsoulis et al. (1973) using insulin ( $0 \cdot 25$ $\mathrm{u} / \mathrm{kg}$ given i.v.), LH/FSH-RH (100 $\mu \mathrm{g}$ i.v.) and TRH
(200 $\mu$ g i.v.). Cortisol was measured by the competitive protein binding method of Beardwell, Burke and Cope (1968). Growth hormone, luteinizing hormone $(\mathrm{LH})$, follicle stimulating hormone (FSH), TSH and prolactin were assayed against the following standards: WHO first IRP for growth hormone, MRC 69/104 for LH and FSH, MRC 68/38 for TSH and Friesen 72-4-9 for prolactin.

The basal and stimulation results are shown in Table 1. The lowest blood sugar was below $35 \mathrm{mg} \%$ 
in all three. All had abnormal tests of growth hormone and gonadotrophin reserve and $\mathrm{K}$ had impaired tests of cortisol and TSH resorve in addition. There was no clear prolactin response to TRH in any of them.

(b) Peripheral tests of thyroid function (Table 2). A was euthyroid on all tests, $\mathbf{S}$ had a borderline protein bound iodine (PBI) and $\mathrm{K}$ was unequivocally hypothyroid on all tests.

(c) Acute metabolic response to human growth hormone. The patients were studied for 4 days before and for 6 days on intramuscular human growth hormone (Crescormon: Kabi) using a dose of $10 \mathrm{iu}$ daily in $\mathrm{A}$ and $\mathrm{S}$ and 12 iu daily in $\mathrm{K}$. Blood urea, urine urea and urine calcium levels were followed on a constant protein intake and a calcium intake of $2 \mathrm{mEq} / \mathrm{kg} / \mathrm{day}$. The mean changes that occurred during the treatment period are shown in Table 3. These changes were compared with the changes found by Melvin et al. (1967) in hypopituitary subjects given 10 iu of human growth hormone intramuscularly daily for 3 days.

\section{Discussion}

It has been suggested that in idiopathic hypopituitarism, trophic hormone deficiencies are acquired progressively (Goodman et al., 1968). Our findings of a more severe endocrine deficiency state in the eldest, $\mathrm{K}$, as compared with the other two children would support this, and clearly she did not have thyroid deficiency from birth as there is nothing to suggest cretinism. The consanguinity and familial occurrence would likewise support the existing evidence for an autosomal recessive mode of inheritance.

From the impaired growth hormone reserve tests, it is not possible to distinguish hypothalamic from pituitary disease. The impaired TSH test in $\mathrm{K}$ with a slightly higher TSH level at $60 \mathrm{~min}$ as compared with the level at 30 min would suggest a hypothalamic lesion according to Hall et al. (1972). An absent gonadotrophin response to LH/FSH-RH would not exclude hypothalamic disease nor necessarily indicate a pituitary lesion in this situation as the pituitary could be refractory to acute $\mathrm{LH} /$ FSH-RH stimulation after a prolonged lack of stimulation.

It is clearly inappropriate to relate sella turcica size to chronological age in dwarfed children. The alternative indices to which sella size can be related are skeletal age and height. The relatively large sellae in $A$ and $K$ in relation to these indices remain unexplained and no similar cases have been reported.

\section{Future management}

As all three are deficient in growth hormone and show an acute metabolic response to this hormone, it is proposed to treat them with Crescormon on a twice weekly basis. $K$ will also receive thyroxine replacement therapy.

\section{Acknowledgments}

We acknowledge with thanks the assistance of the nursing staff of the Metabolic Unit and the technical staff of the Immunoassay Laboratory, Hammersmith Hospital, and expert dietary supervision by Miss P. Dayus. We thank Dr W. Bogie of Hoechst Pharmaceuticals for supplies of TRH and LH/FSH-RH.

\section{References}

Beardwell, C.G., Burke, C.W. \& Cope, C.L. (1968) Urinary free cortisol measured by competitive protein binding. Journal of Endocrinology, 42, 79.

Chaussain, J.L., Garnier, P.E., Milhaud, G. \& Job, J.C. (1972) Etude de l'effect des hormones de libération de la TSH (TRH) et de la LH (LHRH) dans les hypopituitarismes. Annales de Médecine Interne (Paris), 123, 1041.

Clayton, B.E., Tanner, J.M. \& Vince, F.P. (1971) Diag nostic and prognostic value of short term metabolic response to human growth hormone in short stature. Archives of Diseases in Childhood, 46, 405.

Fisher, R.L. \& DI CHIRo, G. (1964) The small sella turcica. American Journal of Roentgenology and Nuclear Medicine, 91, 996.

Franchimont, P., Becker, H., Ernould, $\mathrm{Ch}_{\text {., }}$ Thys, $\mathrm{CH}$ Demoulin, A., Bourguignon, J.P., Legros, J.J. VALCKE, J.C. (1974) The effect of hypothalamic luteinising hormone releasing hormone (LHRH) on plasma gonado trophin levels in normal subjects. Clinical Endocrinolog 3, 27.

Goodman, H.G., Grumbach, M.M. \& Kaplan, S.L. (1968) Growth and growth hormone: A comparison of isolated growth hormone deficiency and multiple pituitary hormone deficiencies in 35 patients with idiopathic hypopituitary dwarfism. New England Journal of Medicine, 278, 57.

Hall, R., Ormston, B.J., Besser, G.M., Cryer, R.J. \& MCKENDRICK (1972) The thyrotrophin-releasing hormone test in diseases of the pituitary and hypothalamus. Lancet, $\mathbf{i}$, 759.

Harsoulis, P., Marshall, J.C., Kuku, S.F., Burke, C.W. \& LoNDON, D.R. (1973) Combined test for assessment of anterior pituitary function. British Medical Journal, 4, 326.

Job, J.C., Lejeune, C., Canlocke, P. \& Rossier, A. (1972) Le nanisme par insuffisance hypophysaire sporadique et idiopathique. Archives Françaises de Pédiatrie, 29, 117.

Melvin, K.E.W., Wright, A.D., Hartog, M., Antcliff, A.C., Copestake, A.M. \& Fraser, T.R. (1967) Acute metabolic response to human growth hormone in different types of dwarfism. British Medical Journal, 3, 196.

Silverman, F.N. (1957) Roentgen standards for size of the pituitary fossa from infancy through adolescence. American Journal of Roentgenology, 78, 451.

TANNER, J.M. (1958) Modern Trends in Paediatrics (Ed. by A. Holzel and J. P. M. Tizard), p. 325. Butterworth Medical Publishers, London.

Trygstad, O. \& SeIP, M. (1964) Hereditary pituitary dwarfism treated with human growth hormone. Acta paediatrica scandinavica, 53, 527.

Under WoOd, L.E., Radcliffe, W.B., Strickland, A.L. \& VAN WYK, J.J. (1973) Assessment of the sella turcica volume in dwarfed children. Journal of Clinical Endocrinology and Metabolism, 36, 734. 